\title{
Rationalization of Digital Media in Developing Market Potential for Retail Products: Case Study in Welcoming Industry 5.0
}

\author{
Kusumah Arif Prihatna ${ }^{1}$, Yoyoh Hereyah ${ }^{2}$ \\ \{kusumah.arif@binus.ac.id ${ }^{1}$,yoyoh.hereyah@mercubuana.ac.id² \\ Bina Nusantara University, Indonesia ${ }^{1}$ \\ Mercu Buana University, Indonesia ${ }^{2}$
}

\begin{abstract}
Digital media is a form of technological advance in Industry 4.0 that entrepreneur can utilize it to reach customers. This research aims to analyze, describe, and explain the rationalization of various digital media usage in an integrated manner as a means of marketing communication in an effort to develop the market potential of a product in the current industrial environment with the possibility of enhancement to face industry 5.0. The research was conducted on the issue of the development of product market potential using Qualitative approach and Case Study method toward entrepreneurial firm in retail product. The findings are, the digital media as an important part of industry 4.0 have their respective roles and complement each other as marketing communication tools, and are used in an integrated way to provide information and attract customers. However, even though the industry is moving forward, the business in this case study has no preparation in welcoming industry 5.0 other than the usage of digital media and internet connection (IoT).
\end{abstract}

Keywords: rationalization, entrepreneurship, digital media, concept of digital media, marketing communication, market potential development, retail product, industry 4.0 , industry 5.0

\section{Introduction}

Digital media had emerged in the 21 st century due to two things, the impetus of technological advancement, and the interaction of audiences towards the technology itself, which leads to the usage of digital media in the field of marketing to reach customers [1][2]. Thus, marketing had been shifted to the digital media, giving the effect to online marketing that able to touch consumer widely [3]. Digital media enables interconnectivity and real time data coupled with the possibility of machine learning, and automation that is able to be applied to digital marketing [4][5]. Therefore, communication related to marketing subject has entered the industry 4.0 [6][7]. When the marketing and communication has entered the industry 4.0, so does the entrepreneurship [8]. Industry 4.0 refers to IoT (Internet of Things), which are things, in form of modern technologies, that are useful only when they are connected to the internet in order to manage data, to provide service, and other activities related to data communication [9]. The technology is still advancing as we are now facing Industry 5.0, the era with more advance than just involving IoT. It is an era of 
complementary interaction between AI (artificial intelligence), humans, things (machine or device), and internet [10][11].

As part of the IoT, there are many well-known types of digital media that have their own characteristic for social relation in the form of social media and its derivatives, the chat application [12]. Firms can utilize digital media and use it as a tool for marketing communication as part of a marketing strategy. Hence, the question arises, how can firms find which digital media has the effectiveness in reaching potential customers? Rationalization provides a reasonable explanation. Rationalization is the action of reorganizing a process, or system so as to make it more logical and consistent, which means a process of digital media usage as to make it more logical and consistent [13]. Firms must have a logical and consistent system to take advantage of digital media that has effectiveness in reaching customers [14].

The research of digital media for marketing purpose, or so-called digital marketing, has been done previously meriting further research [15][16]. And so does the relation to the research of digital marketing communication, which has the impact of consumer buying decision [17]. Digital marketing communication refers to marketing communication via digital media [6]. Several researches on digital media for marketing have been conducted with the conclusion as follow: website has become a fundamental marketing tool [18], email has an influencing factor as marketing media [19], YouTube has the ability to build awareness [20], Instagram has an effectiveness of visual social network sites as a marketing platform [21], Facebook is an ideal leverage for the drivers of marketing [22], Twitter has important implications for marketing [23], platforms such as Facebook, Twitter, WhatsApp, and Instagram have become known for linking individuals through text, pictorial, and video messaging, thus creating a way of passing information to customers instantly in a way that creates appeal [24].

The results of those researches within Industry 4.0 provide a general conclusion that digital media has a great influence as a media for marketing. However, those researches dealt with the use of digital media singly, not as a complement to each other. Furthermore, there wasn't much research on chat applications, as derivative of social media, as a media for marketing, other than WhatsApp [24]. Therefore, this empirical paper has been conducted to fulfill the gap related to the interaction of complementary digital media, marketing communication, and market development in the sense of rationalization in industry 4.0 while evaluating the readiness in welcoming industry 5.0. Thus, the research goal is, within the scope of IoT, to find out the more logical and consistent digital media related to how, why, what kind of digital media that can support certain marketing communication in order to develop market potential of a retail product, in this case, a snack product. Market development is a growth strategy whereby firms are trying to sell existing products to new markets through opening up previously excluded market segments by entering new geographic market and setting new marketing campaign and creates new distribution channels. This strategy allows firms to use brand names that have been developed in a single market segment to reach or discover new market segments [25][26].

A preliminary survey conducted earlier and gave feedback about digital media and marketing communication used based on marketing strategi of the firm. Some of the digital media were still relevant during the process of collecting data, thus the digital media used (or previously used) are Website [27], Email [28], Instagram [29], Facebook [30], Twitter [31], YouTube [32], WhatsApp [33], Line [34], and Blackberry Messenger [35]. And the marketing communication used are Advertising, Personal Selling, Publicity \& Public Relation, and Customer Service [36]. 
Digital media, as a marketing communication tool, was analyzed using the concept in which marketing communication can be influenced by it in order to assess the contribution of digital media toward marketing communication [37]. There are eight concepts, namely:

a. Interactivity; refers to a condition in which there are two or more parties that can communicate about the message delivered in approximately the same time through a medium. A digital communication allows interactivity with regard to a message that can be responded at almost the same time [37][38].

b. Multichannel marketing; refers to marketing methods using more than one marketing channel. The application of this marketing is the use of a single strategy on various marketing channels with the aim of maximizing the possibility of getting customer [37][39].

c. Personalization; refers to product customization and purchasing experience to individual consumer tastes based on their personal information and preferences. Digital media allows personal messaging to be communicated between firms and consumers so as to better align corporate goals and market segmentation, provoke feedback, and form new strategies on marketing [37][40]

d. Mobility; refers to the ability to move or move freely and easily. With the existence of wireless devices such as Smartphone and the availability of Internet networks that allow transactions to be made in real time and at any location, then a form of marketing communications can be done wherever there are Internet and cell phone networks [37][41].

e. Speed; refers to the progress of information systems and technologies that enable marketing communication to be done and delivered at a much faster pace than traditional media. This speed is also related to direct communication to the consumer both in terms of marketing or feedback [37][42].

f. Efficiency; refers to doing things right, whatever is done, is carried out in the most appropriate way, according to available resources. Digital media reduces wasted communication by directing messages to the target segment without excessive effort [37][43].

g. Enhanced relationship; refers to enabling the increase levels of a relationship while enhancing the customer's desire for the unique characteristics found in a relationship. Digital media is used by firms to collect and use information about customers in order to better meet their needs so as to help develop new forms of sales promotion and influence customer relationships [37][44].

h. Strategic implications; refers to influences on corporate planning. Strategic implications are the main consequences arising from the unintelligible and the ability to cope with the effects of power and the dynamics of the diverse changes that can often affect business from the point of view due to technological advances [37][45].

Marketing communication refers to ways of communication in marketing of products or services [46]. Based on preliminary research, there are four marketing communication tools used as objects of research.

a. Advertising; refers to online or digital advertising that uses the internet for the express purpose of delivering marketing messages, and giving the introduction of new products designed to compete with existing brands. Advertising help marketers reaching consumer and fulfilling marketing objectives by providing consumers with useful information to influence their attitudes and behavior [46] [47] 
b. Publicity \& public relation; publicity is the disclosure of the story of the brand that is done through the media without a change, while public relations is an attempt to generate and control publicity in an effort to gain support and community cooperation. Publicity acts as editorial space of an information to promote a product, place, or person and it disseminated through various media to attract public notice. And public relations acts to build image that tends to deal with issues rather than products or services [46] [48][49]

c. Personal selling; refers to interpersonal communication whereby the seller discloses and meets customer needs that benefit both parties. Personal selling is considered an effective marketing communication since it has direct exchange process between a buyer and a seller [46] [50].

d. Customer Service which refers to corporate interactions with customers representing the company's overall business. Customer Service relates to provision of general product information and having the intangible relationship between buyer and seller [46] [51].

\section{Research Method}

The subject of research is the marketing and sales strategies of Cireng Salju which are tiered in each region that has been determined exclusively for each distributor, and the distributor provides the product exclusively for agent, reseller, or customer only in the area that is the responsibility of the distributor. The product is not available in offline stores, as the consequence, the firm depends heavily on digital media. Thus, the object of the research is rationalization of digital media involving the interplay and complementary to the maximum effect that can develop market potential with the possibility of welcoming industry 5.0. Cireng Salju is a product of entrepreneurship where the cireng, which are usually sold as roadside fritters, are converted into packaging products. This research employed qualitative approach since researcher strongly believe that there are multiple perspectives to be uncovered closely by researcher and the strategy of case study in which the researcher explores in depth to more than one key informant that are bounded by time [52].

The answers from the interview results, which were used as research material, must be within the scope of the concept of digital media as a corridor to reach the conclusions sought. Primary data were collected thru interview from selected key informants, which consist of parties representing (1) manufacturer, (2) exclusive distributors, (3) agents, (4) reseller, and (5) customer, based on purposive sampling, which is to sample cases/participants in a strategic way so that those sampled are relevant to the research questions that are being posed based on literature review. Secondary data were collected by observing digital media used by the company. All data were analyzed using Miles \& Huberman interactive analysis technique, through data reduction, data presentation, and conclusion/verification. Furthermore, the validity of the data is verified using triangulation that entails the analysis of the same source by combining several different angles or perspectives [53].

\section{Results and Discussion}

This research explores data from: marketing managers as the representatives of firms; distributors as consumer intermediaries who represent firms, and the representation of the 
consumers themselves. The tree sided data resources are required to meet the triangulation criteria [54]. The research showed that not all digital media is appropriate as a means of marketing communications tool. The concept of strategic implications support Publicity \& Public Relation through the website, as well as Advertising which is combined with the concept of mobility and multichannel marketing. Other concepts cannot support any form of marketing communication. However, for the concept of speed and efficiency, not all interviewee rejected the idea that this concept can support Advertising via website. Website can be accessed from mobile device which is suitable for Advertising and Publicity \& Public Relations. Firms can put hyperlink to other digital media in the website so it can link to other digital media. Website provides information about company and products and has great deal in strategic implication.

... website can be viewed through a mobile phone; it is definitely mobile.... if there is an advanced business to reach consumers, he must use the internet, so that producers can later gather information as a basis for further steps. Manufacturers can publish detail related to the company or product information or advertisement on the website and hyperlinked it to social media ...

Email is not suitable for Advertising, Publicity \& Public Relation, Personal Selling, and Customer Service., and only suitable none other for corporate administration purposes only. Email is mostly used for management issue; thus, the concept of digital media does not affect the marketing communications associated with email as a means of marketing communication.

...every time we do an evaluation related to the influence of using social media on the market, what kind of effectiveness, and finally we adjust, including the Website and Email. The email we use is for office purposes only.

Instagram is suitable for Advertising since it is supported by mobility, speed, and efficiency, multichannel marketing, and strategic implications. As for Publicity \& Public Relation, it is supported only by the concept of strategic implications. Instagram was designed for mobile user and spoiling users for instant status updates in the form of images or photos with no additional charge. The growth of Instagram user makes this digital media has strategic implication. However, even though Instagram has facility to interact, it is not suitable for Personal Sales and Customer Service. If there is an advanced business to reach consumers, he must use the Internet, so that producers can later gather information as a basis for further steps. Manufacturers can publish info related to info or advertise on Instagram and connect it to other social media... it is intended for mobile applications, so that the application does move...the mobile app is very helpful when you want to post info or to advertise since it can be uploaded directly and efficient.

Twitter actually can support Advertising, Publicity \& Public Relation, as well as Personal Selling and Customer Relationship. That is at least the opinion from the representatives of firms as once he used this social media as prime digital media for marketing until he realized that Twitter is not suitable to market a product. Interviewee found that Twitter was not convenient enough to be used for selling or marketing.

We used Twitter before. And it's quite helpful to advertise there and get some reactions or comments or even orders but we never use them again. Twitter is only a witness or time marker when we start this business. I think customer tend to use Instagram or maybe Facebook to get an update about new products

Facebook supports Advertising and, at some point, Publicity and Public Relation. Just like Instagram, Advertising is supported by the concepts of mobility, speed, efficiency, multichannel marketing, and strategic implications. And Strategic Implications also supports 
Publicity \& Public Relation. Facebook has a large number of users as well as features that support sales or marketing, thus Facebook is suitable for Advertising and Publicity \& Public Relations. Personal Sales and Customer Service can be accommodated via Facebook, but somehow users feel uncomfortable to interact directly via Facebook

Facebook is interactive enough for Advertising and it can be hyperlinked to Website. Customer can comment and respond to our posting of activities, thus creates bonding with us. I like to use these two to market the product. But I don't use it to chat with the customer

WhatsApp is more suitable for Personal Selling and Customer Service, since it supports all the aspects of digital media except for Personalization since all interviewee have no consideration about personalizing the product. And not all interviewer rejected the idea of Advertising is supported by the concept of multichannel marketing, since it can be hyperlinked to other media. The basic reason why WhatsApp is mostly suitable for Personal Sales and Customer Service is due to its form of instant messaging service.

WhatsApp is a mobile application, so as I confirmed before, we can use it on a mobile basis and efficiently.... I think I can use WhatsApp to advertise products or maybe for publicity but it will not be efficient. To share all content one by one, or to spread it at once to all of my contacts, it doesn't seem the right step ..... WhatsApp is proven as the right media to create personal interaction with the customer, or to my distributors, agents, and reseller. As for impact, off course we can measure the next step based on our interaction with customer via WhatsApp

LINE and BBM have the same purpose and characteristic with WhatsApp. However, due to consideration that LINE is not used widely in Indonesia, and BBM is not popular anymore, LINE and BBM are not used as digital media for the purpose of marketing communication.

We never used LINE to market our product or get connected to our customer primarily. We just have it but I guess LINE is for the youngster, not for business. We used BBM before, but now it's just not efficient, nobody use it anymore. .

YouTube is not suitable for Personal Selling, Customer Service, and Publicity \& Public Relation since users cannot found usable information related to company and products. However, it is suitable for Advertising and Publicity \& Public Relation as supported by the concept of strategic implication

We publish our activities in YouTube because we thought that everybody use YouTube, and I think it is good to develop our reputation

These basic findings were consistent with previous research showing that digital marketing communication is one of the most important industrial marketing communication tools and enhance customer relationship communications, support sales, create awareness thus can attract consumer within the environment of industry 4.0 [55]. The concept of mobility broadly supported all digital media because generally access to content was done via mobile phones, however, based on interviews it was known that some digital media were no longer used for marketing activities, so those digital media were considered unsupported by the concept of digital media.

The results of the interviews showed that advertising on digital media was supported by the concept of mobility, multichannel marketing, speed, efficiency, and strategic implication on website, Instagram, and Facebook. Advertising on digital media was also supported by the concept of multichannel marketing on WhatsApp and by the concept of strategic implication on YouTube. Publicity and public relation on digital media on digital media were supported by the concept of strategic implication on website, Instagram, Facebook, and YouTube. Personal selling and customer service on digital media was supported by the 
concept of interactivity, mobility, speed, efficiency, enhanced relationship, and strategic implication on WhatsApp.

Table 1. Interview Result after Validation

\begin{tabular}{|c|c|c|c|c|}
\hline & Advertising & $\begin{array}{l}\text { Publicity \& Public } \\
\text { Relation }\end{array}$ & Personal Selling & Customer Service \\
\hline Website & $\begin{array}{l}\text {-Mobility } \\
\text {-Multichannel } \\
\text { Marketing } \\
\text {-Speed (partially } \\
\text { agree) } \\
\text {-Efficacy (partially } \\
\text { agree) } \\
\text {-Strategic } \\
\text { Implications }\end{array}$ & $\begin{array}{l}\text {-Strategic } \\
\text { Implications }\end{array}$ & none & none \\
\hline Email & none & none & none & none \\
\hline Instagram & $\begin{array}{l}\text {-Mobility } \\
\text {-Multichannel } \\
\text { Marketing } \\
\text {-Speed } \\
\text {-Efficiency } \\
\text {-Strategic } \\
\text { Implications }\end{array}$ & $\begin{array}{l}\text {-Strategic } \\
\text { Implications }\end{array}$ & none & none \\
\hline Twitter & none & none & none & none \\
\hline Facebook & $\begin{array}{l}\text {-Mobility } \\
\text {-Multichannel } \\
\text { Marketing } \\
\text {-Speed } \\
\text {-Efficiency } \\
\text {-Strategic } \\
\text { Implications }\end{array}$ & $\begin{array}{l}\text {-Strategic } \\
\text { Implications }\end{array}$ & none & none \\
\hline WhatsApp & $\begin{array}{l}\text {-Multichannel } \\
\text { Marketing } \\
\text { (partially agree) }\end{array}$ & none & $\begin{array}{l}\text {-Interactivity } \\
\text {-Mobility } \\
\text {-Speed } \\
\text {-Efficiency } \\
\text {-Enhanced } \\
\text { Relationships } \\
\text {-Strategic } \\
\text { Implications } \\
\end{array}$ & $\begin{array}{l}\text {-Interactivity } \\
\text {-Mobility } \\
\text {-Speed } \\
\text {-Efficiency } \\
\text {-Enhanced } \\
\text { Relationships } \\
\text {-Strategic } \\
\text { Implications } \\
\end{array}$ \\
\hline LINE & none & none & none & none \\
\hline BBM & none & none & none & none \\
\hline YouTube & $\begin{array}{l}\text {-Strategic } \\
\text { Implications }\end{array}$ & $\begin{array}{l}\text {-Strategic } \\
\text { Implications }\end{array}$ & none & none \\
\hline
\end{tabular}

After validation, the result showed that website, Instagram, Facebook, WhatsApp, and YouTube can complement each other to reach customer via advertising, publicity \& public relation, personal selling, and customer care within the concept of interactivity, multichannel marketing, mobility, speed, efficiency, enhanced relationship, and strategic implication. All digital media act as Internet of Thing (IoT) by connecting the content and conversation between manufacturer, exclusive distributors, agents, reseller, and customer. The industrial environment was considered still 4.0 with the small possibility to enter industry 5.0 , the era of complementary interaction between AI (artificial intelligence), humans, things (machine 
or device), and internet [10][11], since all business process was still done manually without any involvement of AI.

The main finding in the research above is the strategy for maximizing the use of digital media as a marketing medium in the industrial environment 4.0 to develop market potential, with the hope of finding the company's readiness to face industry 5.0, which was found that in fact, this industrial environment is not as close as one might think. Nevertheless, the impetus of technological advancement and the interaction of audiences towards the technology itself, refer to digital media, makes it easier for each individual to have a variety of social media accounts. In connection with that, this makes it easier for social media users to be exposed to various forms of marketing [1][2]. In this case marketing communication through website, email, Instagram, Facebook, Twitter, YouTube, WhatsApp, Line, and Blackberry Messenger.

Website can provoke customer engagement [56], purchase intentions [57], and generate satisfaction [58] toward product or service offering so that the website is suitable as a marketing media [18], where in this study, the website was used as an advertising media as well as publicity and public relations. Email can also generate customer engagement. In previous research, email has a role as a marketing medium in the form of direct marketing [59]. However, as it can prove to be a helpful communications asset, email is mostly used for management issues, as expressed by one of the interviewees. In this study, due to direct marketing is not used as one of the marketing communications tools, email was not considered as digital media which could develop market potential.

Instagram facilitate informative visuals that lead to emotional appeal that can influence customer engagement in terms of likes and comments, so that Instagram is very suitable as a marketing media for advertising [60] as well as Facebook [61] with the difference that Instagram is more to emotional expression with real experiences while Facebook is more to wide user without likely used by youngster. However, even though Twitter has a similarity as social media with Instagram, this social media is more to conversation, and the interview result showed that Twitter was not suitable to market a product [62][63][64][65][66].

YouTube allows brands that are yet unfamiliar to a market can create engagement by focusing on advertising elements [65]. And the result showed that YouTube had strategic implication to the firm. WhatsApp is quite powerful tool as chat application to interact and enhanced relationships [67], thus based on interview results, it was suitable for personal selling and customer service. Actually, LINE and BBM have the same characteristic, however, based on based on interview results, these two applications were considered not used widely and has no effect to market development.

\section{Conclusion}

In the era of Industry 4.0, where things are connected to internet, it is common for firm that engaged in retail products to take advantage of the growing use of digital media via mobile phones as a means of marketing communication. However, not all digital media is suitable for marketing communication. Thus, it is required rationalization, which is an understanding in utilizing digital media that can logically support the development of market potential. The appropriate digital media as a marketing communication tool in developing market potential are Website, Facebook, Instagram, and YouTube which are used for 
Advertising and Publicity \& Public Relations. And WhatsApp is used for Personal Sales and Customer Service.

Digital media is used in an integrated way to support the development of market potential where the Website can provide complete information about the product and company, Facebook can help firms spread information to many Facebook users, Instagram can help firms spread information to Instagram users where this social media is being used in social life, YouTube can help firms to spread the reputation, and WhatsApp can help firms to interact with customers because of its ease of use in direct communication. Digital media in the form of Email, Twitter, LINE, and BBM can be a means of marketing communication, but from this research it is concluded that these digital media cannot support the the development of market potential.

This paper has limitation, and therefore giving chance to further study about marketing communication and digital media. The surveyed digital media are based on preliminary research, thus put aside the digital media is currently on the rise, tiktok. Advertising, Publicity \& Public Relations, Personal Sales, and Customer Service are suitable in the environment of Industry 4.0 and further in Industry 5.0, where marketing communication strategies are applied to things connected to the internet (IoT). The right information can entice the interest of digital media audiences to become customers and can generate interest to work as distributors, agents, or resellers to develop market potential. However, since Industry 5.0 is an era of complementary interaction between humans, things (machine or device), and internet, the result of interview showed that the firm is not ready, and firm must have advance preparation than just IoT.

\section{References}

[1] O. Ungerman and J. Dědková, "Marketing Innovations in Industry 4.0 and Their Impacts on Current Enterprises," Appl. Sci., vol. 9, no. 18, p. 3685, Sep. 2019.

[2] K. Nosalska and G. Mazurek, "Marketing Principles for Industry 4.0 - A Conceptual Framework," Eng. Manag. Prod. Serv., vol. 11, no. 3, pp. 9-20, Nov. 2019.

[3] W. Wereda and J. Woźniak, "Building Relationships with Customer 4.0 in the Era of Marketing 4.0: The Case Study of Innovative Enterprises in Poland," Soc. Sci., vol. 8, no. 6, p. 177, Jun. 2019.

[4] Y. Li, J. Dai, and L. Cui, "The Impact of Digital Technologies on Economic and Environmental Performance in the Context of Industry 4.0: A Moderated Mediation Model," Int. J. Prod. Econ., vol. 229, p. 107777, Nov. 2020.

[5] A. Warokka, H. Sjahruddin, S. Sriyanto, E. Noerhartati, and K. Saddhono, "Digital marketing support and business development using online marketing tools: An experimental analysis," Int. J. Psychosoc. Rehabil., vol. 24, no. 1, 2020.

[6] J. Kim, S. Kang, and K. H. Lee, "Evolution of Digital Marketing Communication: Bibliometric Analysis and Network Visualization from Key Articles,” J. Bus. Res., Nov. 2019.

[7] M. Bartosik-Purgat, "Digital Marketing Communication from the Perspective of Individual Consumers: A Cross-Country Comparison,” Entrep. Bus. Econ. Rev., vol. 7, no. 3, pp. 205220, 2019.

[8] E. Kurniawati, I. H. Al Siddiq, and I. Idris, "E-Commerce Opportunities in the 4.0 Era Innovative Entrepreneurship Management Development,” Polish J. Manag. Stud., vol. 21, no. 1, pp. 199-210, Jun. 2020.

[9] L. Belli, L. Davoli, A. Medioli, P. L. Marchini, and G. Ferrari, "Toward Industry 4.0 With IoT: Optimizing Business Processes in an Evolving Manufacturing Factory," Front. ICT, vol. 6, Aug. 2019. 
[10] V. Potočan, M. Mulej, and Z. Nedelko, "Society 5.0: balancing of Industry 4.0, economic advancement and social problems," Kybernetes, vol. ahead-of-p, no. ahead-of-print, May 2020.

[11] P. Sachsenmeier, "Industry 5.0-The Relevance and Implications of Bionics and Synthetic Biology," Engineering, vol. 2, no. 2, pp. 225-229, 2016.

[12] G. De Prato, E. Sanz, and J. P. Simon, Digital Media Worlds The New Economy of Media. New York: Palgrave Macmillan, 2014.

[13] W. Outhwaite, The Blackwell Dictionary of Modern Social Thought, 2nd ed. Hoboken, New Jersey: John Wiley \& Sons, 2008.

[14] C. Bauer and P. Lasinger, "Adaptation Strategies to Increase Advertisement Effectiveness in Digital Media,” Manag. Rev. Q., vol. 64, no. 2, pp. 101-124, 2014.

[15] J. M. Müller, B. Pommeranz, J. Weisser, and K.-I. Voigt, "Digital, Social Media, and Mobile Marketing in Industrial Buying: Still in Need of Customer Segmentation? Empirical Evidence from Poland and Germany," Ind. Mark. Manag., vol. 73, pp. 70-83, 2018.

[16] Y. K. Dwivedi et al., "Setting the Future of Digital and Social Media Marketing Research: Perspectives and Research Propositions,” Int. J. Inf. Manage., no. June, p. 102168, Jul. 2020.

[17] R. Dahiya and G. Gayatri, "A Research Paper on Digital Marketing Communication and Consumer Buying Decision Process: An Empirical Study in the Indian Passenger Car Market," J. Glob. Mark., vol. 31, no. 2, pp. 73-95, 2018.

[18] N. Daries-Ramon, E. Cristobal-Fransi, and E. Mariné-Roig, "Deployment of Restaurants Websites' Marketing Features: The Case of Spanish Michelin-Starred Restaurants,” Int. J. Hosp. Tour. Adm., vol. 20, no. 3, pp. 249-280, Jul. 2019.

[19] R. R. Sharma and B. Kaur, "E-mail Viral Marketing: Modeling the Determinants of Creation of "Viral Infection," Manag. Decis., vol. 58, no. 1, pp. 112-128, Jan. 2020.

[20] M. T. Febriyantoro, "Exploring Youtube Marketing Communication: Brand Awareness, Brand Image and Purchase Intention in the Millennial Generation," Cogent Bus. Manag., vol. 7, no. 01, Jan. 2020.

[21] L. X. Teo, H. K. Leng, and Y. X. P. Phua, "Marketing on Instagram: Social Influence and Image Quality on Perception of Quality and Purchase Intention," Int. J. Sport. Mark. Spons., vol. 20, no. 2, pp. 321-332, May 2019.

[22] M. Fink, M. Koller, J. Gartner, A. Floh, and R. Harms, "Effective Entrepreneurial Marketing on Facebook - A Longitudinal Study," J. Bus. Res., vol. 113, pp. 149-157, May 2020.

[23] X. Jin and M. Cheng, "Communicating Mega Events on Twitter: Implications for Destination Marketing,” J. Travel Tour. Mark., vol. 37, no. 6, pp. 739-755, Jul. 2020.

[24] M. T. Nuseir, "Is Advertising on Social Media Effective an Empirical Study on the Growth of Advertisements on the Big Four (Facebook, Twitter, Instagram, Whatsapp)," Int. J. Procure. Manag., vol. 13, no. 1, p. 134, 2020.

[25] F. Eggers, I. Hatak, S. Kraus, and T. Niemand, "Technologies That Support Marketing and Market Development in SMEs-Evidence from Social Networks,” J. Small Bus. Manag., vol. 55, no. 2, pp. 270-302, Apr. 2017.

[26] J. Zentes, D. Morschett, and H. Schramm-Klein, "Growth Strategies," in Strategic Retail Management, Wiesbaden: Springer Gabler, 2017, pp. 141-161.

[27] M. Javed Akhtar, Z. Ahmad, and R. Amin, "An Efficient Mechanism for Product Data Extraction from E-Commerce Websites," Comput. Mater. Contin., vol. 65, no. 3, pp. 26392663, 2020.

[28] Z. Albert, "Click to Subscribe: Interest Group Emails as A Source of Data," Interes. Groups Advocacy, vol. 9, no. 3, pp. 384-395, Sep. 2020.

[29] G. S. Cornelio and A. Roig, "Mixed Methods on Instagram Research: Methodological Challenges in Data Analysis and Visualization," Converg. Int. J. Res. into New Media Technol., Aug. 2020.

[30] M. Kowal et al., "Reasons for Facebook Usage: Data From 46 Countries," Front. Psychol., vol. 11, Apr. 2020.

[31] T. Al Baghal, L. Sloan, C. Jessop, M. L. Williams, and P. Burnap, "Linking Twitter and 
Survey Data: The Impact of Survey Mode and Demographics on Consent Rates Across Three UK Studies," Soc. Sci. Comput. Rev., vol. 38, no. 5, pp. 517-532, Oct. 2020.

[32] A. N. Patterson, "YouTube Generated Video Clips as Qualitative Research Data: One Researcher's Reflections on the Process," Qual. Inq., vol. 24, no. 10, pp. 759-767, Dec. 2018.

[33] K. A. Prihatna, R. Ayal, M. Sistarani, and Y. Christanti, "What Whatsapp Status Enables Reseller to Do as Channel,” Int. J. Innov. Technol. Explor. Eng., vol. 8, no. 9S3, pp. 44-55, Aug. 2019.

[34] M. Steinberg, "LINE as Super App: Platformization in East Asia," Soc. Media + Soc., vol. 6, no. 2, p. 205630512093328 , Apr. 2020.

[35] F. Scheuermeyer, B. Grunau, J. Cheyne, E. Grafstein, J. Christenson, and K. Ho, "Speed and Accuracy of Mobile Blackberry Messenger to Transmit Chest Radiography Images from a Small Community Emergency Department to a Geographically Remote Referral Center," J. Telemed. Telecare, vol. 22, no. 4, pp. 244-251, Jun. 2016.

[36] T. A. Shimp, Advertising Promotion and Other Aspects of Integrated Marketing Communications. Cengage Learning, 2008.

[37] C. Fill, Marketing Communications: Interactivity, Communities and Content. Harlow, Edinburgh: Pearson Education Limited, 2009.

[38] S. S, J. Paul, C. Strong, and J. Pius, "Consumer Response towards Social Media Advertising: Effect of Media Interactivity, Its Conditions and the Underlying Mechanism," Int. J. Inf. Manage., vol. 54, p. 102155, Oct. 2020.

[39] S. Banerjee and P. Bhardwaj, "Aligning Marketing and Sales in Multi-Channel Marketing: Compensation Design for Online Lead Generation and Offline Sales Conversion,” J. Bus. Res., vol. 105, pp. 293-305, Dec. 2019.

[40] K. T. Smith, "Mobile Advertising to Digital Natives: Preferences on Content, Style, Personalization, and Functionality," J. Strateg. Mark., vol. 27, no. 1, pp. 67-80, Jan. 2019.

[41] T. A. Oliveira et al., "Mobility, Citizens, Innovation and Technology in Digital and Smart Cities," Futur. Internet, vol. 12, no. 2, p. 22, Jan. 2020.

[42] I. Arieli, Y. Babichenko, R. Peretz, and H. P. Young, "The Speed of Innovation Diffusion in Social Networks," Econometrica, vol. 88, no. 2, pp. 569-594, 2020

[43] M. Binsawad, "Social Media Efficiency towards Restaurant Business: A Comparison between Social Media Profiles (Case Study in Saudi Arabia)," Multimed. Tools Appl., vol. 79, no. 4142, pp. 89-99, Nov. 2020.

[44] S.-H. Chuang, "Co-Creating Social Media Agility to Build Strong Customer-Firm Relationships,” Ind. Mark. Manag., vol. 84, pp. 202-211, Jan. 2020.

[45] M. Pittman and K. Sheehan, "Brand Authenticity and Strategic Response to Crises: Symbolic Effects of Donation Type on Purchase Intent and Digital Engagement," J. Curr. Issues Res. Advert., pp. 1-21, Mar. 2020.

[46] H. Ouwersloot and T. Duncan, Integrated Marketing Communication, European. Berkshire: McGraw-Hill Education, 2008

[47] H. Lee and C.-H. Cho, "Digital advertising: present and future prospects," Int. J. Advert., vol. 39, no. 3, pp. 332-341, Apr. 2020.

[48] S. Waisbord, "Trolling Journalists and the Risks of Digital Publicity," Journal. Pract., pp. 117, Sep. 2020

[49] M. Gesualdi, "Revisiting the relationship between public relations and marketing: Encroachment and social media," Public Relat. Rev., vol. 45, no. 2, pp. 372-382, Jun. 2019.

[50] H. Kurata, "Is the Information of Customer Types and Preferences to Personal Selling Worth the Investment in Innovative Technology? A Modeling Approach," J. Retail. Consum. Serv., vol. 49, pp. 371-379, Jul. 2019.

[51] T. J. Bacile, "Digital Customer Service and Customer-To-Customer Interactions: Investigating the Effect of Online Incivility on Customer Perceived Service Climate," J. Serv. Manag., vol. 31, no. 3, pp. 441-464, Jun. 2020.

[52] J. W. Creswell and J. D. Creswell, Research Design: Qualitative, Quantitative, and Mixed Methods Approaches. SAGE Publications, 2017. 
[53] J. S. Matthew B. Miles, A. Michael Huberman, Qualitative Data Analysis. SAGE Publications, Inc., 2014.

[54] A. Bryman, Social Research Methods, 4th ed. New York: Oxford University Press Inc., 2012.

[55] A. Rangaswamy, N. Moch, C. Felten, G. van Bruggen, J. E. Wieringa, and J. Wirtz, "The Role of Marketing in Digital Business Platforms," J. Interact. Mark., vol. 51, pp. 72-90, Aug. 2020.

[56] C. Connell, R. Marciniak, L. I. Carey, and J. McColl, "Customer Engagement with Websites: A Transactional Retail Perspective,” Eur. J. Mark., vol. 53, no. 9, pp. 1882-1904, Sep. 2019.

[57] K.-C. Chang, C.-L. Hsu, M.-C. Chen, and N.-T. Kuo, "How a Branded Website Creates Customer Purchase Intentions," Total Qual. Manag. Bus. Excell., vol. 30, no. 3-4, pp. 422 446, Feb. 2019.

[58] S. Dhingra, S. Gupta, and R. Bhatt, "A Study of Relationship Among Service Quality of ECommerce Websites, Customer Satisfaction, and Purchase Intention,” Int. J. E-bus. Res., vol. 16, no. 3, pp. 42-59, Jul. 2020.

[59] J. K. Elrod and J. L. Fortenberry, "Direct Marketing in Health and Medicine: Using Direct Mail, Email Marketing, And Related Communicative Methods to Engage Patients," BMC Health Serv. Res., vol. 20, no. S1, p. 822, Sep. 2020.

[60] R. Rietveld, W. van Dolen, M. Mazloom, and M. Worring, "What You Feel, Is What You Like Influence of Message Appeals on Customer Engagement on Instagram," J. Interact. Mark., vol. 49, pp. 20-53, Feb. 2020.

[61] T. Maree and G. van Heerden, "Beyond The 'Like': Customer Engagement of Brand Fans On Facebook," Eur. Bus. Rev., vol. ahead-of-p, no. ahead-of-print, Jan. 2020.

[62] C. Malighetti, S. Sciara, A. Chirico, and G. Riva, "Emotional Expression of \#body on Instagram," Soc. Media + Soc., vol. 6, no. 2, p. 205630512092477 , Apr. 2020.

[63] V. Mhasawade, A. Elghafari, D. T. Duncan, and R. Chunara, "Role of the Built and Online Social Environments on Expression of Dining on Instagram," Int. J. Environ. Res. Public Health, vol. 17, no. 3, p. 735, Jan. 2020.

[64] P. H. B. Ruas et al., "Identification and Characterisation of Facebook User Profiles Considering Interaction Aspects,” Behav. Inf. Technol., vol. 38, no. 8, pp. 858-872, Aug. 2019.

[65] N. Paul and M. Sui, "I Can Feel What You Feel: Emotion Exchanges in Twitter Conversations between Candidates and the Public," J. Polit. Mark., pp. 1-21, Nov. 2019.

[66] C. Yang and Y. Lee, "Interactants and Activities on Facebook, Instagram, and Twitter: Associations between Social Media Use And Social Adjustment To College," Appl. Dev. Sci., vol. 24, no. 1, pp. 62-78, Jan. 2020.

[67] A. García-Gómez, "Learning through Whatsapp: Students' Beliefs, L2 Pragmatic Development and Interpersonal Relationships," Comput. Assist. Lang. Learn., pp. 1-19, Aug. 2020. 